\title{
Exploring the Usage of Digital Content Marketing in Hotels and Travel Agencies in Egypt
}

\section{Mohamed Ezzat}

Lecturer - Tourism studies Department

Faculty of Tourism and Hotels - Minia University

\author{
Ahmed Rady \\ Lecturer - Hotel studies Department \\ Faculty of Tourism and Hotels - Minia University
}

\begin{abstract}
Tourism establishments should provide the content that can answer all the consumers' queries in very attractive and creative ways. The main purpose of this study is to explore the usage of digital content marketing in both hotels and travel agencies in Egypt as a mean of presenting its tourism services to consumers. The questionnaire was used as a mean of collecting data from the sample of which included of marketing managers at (138) four and five-star hotels and (121) travel agencies located in Sharm El Sheikh, Hurghada and Cairo cities, as vital areas where the big presence of four and five-star hotels and travel agencies class A (Egypt hotels guide, 2016). Two questionnaires were designed; the first one was used for the

in Egypt have a high degree of the awareness of digital content marketing. The overall assessment of using digital content marketing (DCM) in travel agencies and hotels was a successful and more effective marketing strategy. The findings showed that there was a statistically significant correlation between each pair in the study dimensions. There were significant differences between travel agencies and hotels in the dimensions of "awareness", "the benefits", "challenges" and "the common tools of digital content marketing". This study presented some useful recommendations for the hotels and travel agencies in Egypt to activate and benefit from the advantages of digital content marketing in offering tourism and hotel services.
\end{abstract} marketing managers of hotels and the other one for the marketing managers of travel agencies. Each questionnaire was divided into a group of key variables that were measured on a five-dimensional Likert scale to determine the attitude of the respondents about the study variables. The validity and reliability of the study tools were practically measured by presenting them to a group of industry experts and statistical experts, as well as they statistically measured by using Cronbach's Alpha coefficient, the Cochran's formula was used to determine the optimal sample size based on the pilot study results. The results indicated that both travel agencies and hotels
Keywords: Digital Content Marketing- Travel Agencies- Hotels- Egypt

\section{Introduction}

Using the content as a marketing strategy has recently undergone a deep evolution, thanks to the spread of digital communications and social networks (Rancati and Gordini,2014). Content strategy is the practice of planning for the creation, delivery, and governance of useful, usable content (Halvorson, 2010). Content Marketing embodies an organization's core brand elements. It uses a variety of media formats such as text, video, photographs, 
audio, presentations, e-books and infographics to tell your brand or company's story. It can be read on a variety of devices including computers, tablets, smartphones and others. It's distributed via owned, third party and social media platforms and it provides measurable results through the use of appropriate calls-to-action and promotional codes (Content Marketing Expert Project, 2014).

The content quality is one of the dimensions determining the attractiveness of virtual information to the consumer that has the impact on customer confidence, satisfaction and loyalty (Rowley, 2008, Pažèraitė and Repovienè, 2016). Content marketing creates value and helps people. It answers questions and provides fundamental, basic information. This, in turn, leads to a situation in which the customer is educated and informed enough to make a decision concerning a potential purchase, or thanks to having this information he can recommend the purchase to his friends, family or superiors (Świeczak, 2012). A content marketing strategy can leverage all story channels (print, online, in-person, mobile, social, etc.), be employed at any and all stages of the buying process, from attention-oriented strategies to retention and loyalty strategies, and include multiple buying groups (Pulizzi, 2012). Content marketing has established itself over the last few years as an important tool in the travel industry, brands are rapidly investing more time and money in creating shareable articles, video, and interactive media across all channels (Skift, 2016).

\section{Objectives of the Study}

The main purpose of this study is to explore the usage of content marketing in both travel agencies and hotels in Egypt. More specifically, the objectives of this current study are as follows:

- Identifying the extent of awareness of digital content marketing in both hotels and travel agencies in Egypt.

- Shedding light on the benefits and challenges of digital content marketing for both travel agencies and hotels in Egypt.

- Exploring the most tools of digital content marketing being used by travel agencies and hotels in Egypt.

- Exploring the most measurement criteria for digital content marketing Success.

\section{Questions of the Study}

1- What is the extent of awareness of digital content marketing in both travel agencies and hotels in Egypt?

2- What are the benefits and challenges of digital content marketing for both travel agencies and hotels in Egypt?

3- What are the most tools of digital content marketing used by travel agencies and hotels in Egypt?

4- What are the most success criteria for digital content marketing?

5- What are the differences between travel agencies and hotels in all dimensions of digital content marketing of the study?

\section{Literature Review}

Content Marketing means to produce quality content, unique, significant, valuable, dynamic and more relevant than its competitors. The content must: 1) be able to generate interest, involving, informing and educating the customer; 2) express all those values that identify the firm in terms of uniqueness, consistency, quality and relevance; 3) proactive, that is able to evolve over time (Lieb, 2011; Rose and Pulizzi, 2011; Jefferson and 
Tanton, 2013; Rancati and Gordini, 2014). Content marketing is "a marketing technique of creating and distributing relevant and valuable content to attract, acquire, and engage a clearly defined and understood target audience with the objective of driving profitable customer action" (Pulizzi, 2012; CMI, 2013 b; 2016 a, Ahmed et al., 2016). Content marketing is defined as "a strategic marketing approach focused on creating and distributing valuable, relevant, and consistent content to attract and retain a clearly defined audience and, ultimately, to drive profitable customer action.” (CMI, 2016 a).

Mathey (2015) defined Content marketing as "the art of communicating with your public without selling anything directly (branded content is part of the content marketing umbrella)". Content marketing is often defined as the art of identifying and understanding the needs of a particular consumer group and as a consequence satisfying these needs in a skilful way (Swieczak Witold, 2012). Ahmed et al. (2016) stated that content marketing is engaging with the community around by sharing information, ideas and experiences that benefit others without asking anything in returns. The content marketing is sharing the information regarding the products and brands to attract others to participate in purchasing activities that create the engagement relationship between consumers and companies.

Content marketing is "The creation of content that is relevant, compelling, entertaining and valuable and this content must be consistently provided to maintain or change the behavior of customers. Content marketing is an essential marketing activity that helps retain customers, acquire new ones and helps companies to build a strong brand." (Duc Le M, 2013). In the digital marketing of hospitality, content marketing means taking a holistic view of all of the digital content and aiming to have this content to answer your customers' needs as opposed to presenting them with just facts. Such content (in whatever form e.g. text, imagery, video, virtual tour etc.) is then distributed through digital marketing channels such as on hotel website, in email marketing campaigns, in social media updates and so on. Content can either be curate or preferably written by hotel staff with a mixture of the two being the optimum from a resources point of view.

According to Marketing Intelligence Report (2015) and Augustini (2014), there are six essential components of content marketing strategy as follow: content creation, content curation, content amplification or distribution, content optimization, content analytics or measurement and content management.

\subsection{Importance of Digital Content Marketing}

The digital content quality of the tourism enterprises is particularly important because it directly influences the perceived image of the company and creates a virtual experience for the consumers (Andreopoulou et al., 2014). Content quality of tourism websites is becoming a critical issue for effective online marketing. Unique and valuable content is becoming the main goal for a company that seeks to attract customers (Gagnon, 2014 and Mathey, 2015). Several features of quality content were mentioned in the studies of many authors (Chasser and Wolfe, 2010; Gagnon, 2014; Schuinanii, 2014). These features can be perceived as content marketing elements. Moreover, high-quality content should have seven separate elements: relevance, informativeness, reliability, value, uniqueness, emotions and intelligence (Pažèraitè and Repovienè, 2016). Mathey (2015) presented six elements for effective content marketing as 
follow: Personal connection, Information, Entertainment, Relevancy, Consistency and Honesty. According to skift (2013), 86\% of B2C marketers use some form of content marketing. Creating useful custom content helps build relationships with the consumer. The number one goal of content marketing is customer retention and loyalty. Over the past few years, the travel industry has seen visual storytelling play an increasingly important role in content marketing, and $92 \%$ of consumers want brands to make ads that feel like a story (PATA, 2016).

Digital content greatly influences consumers in their travel planning, starting with the first stages of the consumer journey. $65 \%$ of leisure travellers research online before they decide where to go, and the. In addition, the video is shared nearly four times more than other forms of content, with over 8 billion video views daily on Facebook, 6 billion on Snapchat, and nearly 5 billion on YouTube (PATA, 2016). for the travel industry, there's nothing greater than the power of video. The video is the future of content marketing, and it is the most impactful form of storytelling in the travel industry (Skift, 2013). Constantinescu-Dobra (2014) found that small and medium companies spent $33 \%$ of the total marketing budget for content marketing and over $60 \%$ of marketers planned to increase this percentage in the future. Moreover, $90 \%$ of US companies are implementing the content strategy in the marketing mix). According to Content Marketing Expert Project, (2014) 60\% of consumers are inclined to buy a product after reading something that concerned it. Content Marketing is used by $91 \%$ of B2B companies and $86 \%$ of B2C (Content Marketing Institute data, 2014).

\subsection{Benefits and Objectives of Content Marketing}

Content Marketing is a marketing technique using knowledge and experience of the company to promote its products or services. The advantage of content marketing in an advertisements-crowded environment that the main goal is not to sell, but to provide brand recognition, Authority, credibility, loyalty and authenticity (Constantinescu-Dobra, 2014). The main point of creating content marketing is to distribute valuable and the consistency of the content itself to the target audience to drive the profitable customer action (Ahmed et al., 2016). Many of the previous studies mentioned the major objectives of the content marketing as follows: Increasing brand awareness or reinforcement, lead conversion and nurturing, lead generation, converting leads into customers, building the image as the industry leader, customer engagement, customer retention, website traffic, and search engine optimization (Rose and Pullizzi, 2011; Gerard, 2014, Holliman and Rowley, 2014; Gerard, 2015). Mackenzie (2016) mentioned many benefits of content marketing as:

- Interesting and relevant content is a clear way in which you can outshine your competitors.

- SEO (search engine optimization): A strategic content strategy gives Google what it craves: unique, regular, relevant and fresh content - Google rewards your organic rankings accordingly.

- Email Marketing: A coordinated content marketing strategy makes the job of sourcing engaging content (imagery, video, copy) for email distribution much easier. Repeat customers and email subscribers will appreciate it too as you won't be filling their inbox yet again with another deal. 


\subsection{Challenges of Content Marketing}

According to Marketing Intelligence Report (2015), the challenges of content marketing for marketers has become how to create, manage, distribute, optimize, analyze, and measure the growing volume of content that is being generated on a daily basis. Moreover, CMI (2013 a, 2015, 2016 b) arranged the challenges of content marketing as Producing Engaging Content, Producing Content Consistently, and Measuring Content Effectiveness, Producing a Variety of Content, Lack of Budget, Finding Trained Content Marketing Professionals, and Lack of Integration across Marketing

\subsection{The Tools for Content Marketing}

Creating good, convincing, educational, funny and helpful content is important, but not sufficient. It is also very important to disseminate the content using all available channels of digital distribution. Publishing content on a website, blog or in the social media may be effective, but it shouldn't be limited to these means (Świeczak, 2012). The most important tactics of content marketing are: social- media posts e-mail newsletters, blog posts/Guest blog posts, e-books, PowerPoint presentations, podcasts, standard videos/Micro-videos, live presentations; webinars, white papers, and corporate sites (Constantinescu-Dobra, 2014, Augustine, 2014, CMI, 2016 c; Gerard, 2015, Mathey, 2015).

Over the past few years, the travel industry has seen visual storytelling play an increasingly important role in content marketing. From industry trend reports from such sources as the Adventure Travel Trade Association and SKIFT to the multitude of travel content producers flooding digital platforms with inspiring content, the video is a dominant force in content marketing for the travel industry.
(PATA, 2016). However, it was noted that a practised success factor for content marketing was to be able to "tell a good story" (Holliman and Rowley, 2014).

Companies use social media content marketing to create the awareness about their brands to the consumers. Through the social media platforms, they engaged with their consumers and built active interaction among them. Hence, it is crucial for the companies to have good content marketing to attract more customers to visit their page, follow the update news and finally repeat the purchase. The main functions of all these platforms are to interact with each other and to share the information about the products and the brands (Ahmed et al., 2016). The Renaissance Hotel has designed two platforms of social media content marketing which called Navigators Platforms and Rlife LIVE program to attract the customers. According to Gutman (2012), content marketing is critical for Renaissance Hotel as it is the currency that drives the relevance and consumer consideration to their brand.

The most popular tools for B2B content marketing according to Content Marketing Expert Project (2014) were:

- $\quad 87 \%$ of B2B content marketers use social media (other than blogs);

- $\quad 83 \%$ of B2B content marketers use articles on their website;

- $\quad 78 \%$ of B2B content marketers use e-Newsletters;

- $\quad 77 \%$ of B2B content marketers use blogs;

- $\quad 71 \%$ of B2B content marketers use case studies;

- $\quad 70 \%$ of B2B content marketers use videos; 


\subsection{Success Criteria for Content Marketing}

There are many techniques and criteria for measuring and analyzing the content marketing success, but it also depends on what kind of goals one wants to achieve and measure. Hence, there are four main types of criteria and metrics for content marketing: consumption, sharing, lead generation and sales metrics. Consumption criteria measure brand awareness and website traffic generated by the content. These metrics are page views, downloads, visitors, time on page and social chatter. Sharing criteria measure the diffusion and the sharing of content amongst a large number of consumers and their network of people. These metrics are likes, shares, tweets, email forwards, and inbound links. Lead generation criteria measure how often content consumption results in a lead. These metrics are email, newsletter, blog subscriptions, blog comments, cookies, and conversion rate. Sales criteria help to identify the impact of $\mathrm{CM}$ on company performance. Examples of these metrics are online sales, customer retention, and cost saving (Elisa and Gordini, 2014, Augustini, 2014, Marketing Intelligence Report, 2015). Hence, Augustini (2014) illustrated that consumption and sharing metrics being used for analysis of the content when building a new campaign and overall content strategy.

\section{Methodology}

\subsection{Research Population and Sample}

The main purpose of this study is to explore the usage of digital content marketing in both travel agencies and hotels in Egypt. To achieve the purpose and objectives of this research, a quantitative approach was used. The study targeted the population of travel agencies and hotels in Egypt. Two questionnaires were designed targeting a sample of the study population. The survey was piloted on a sample of 45 marketing managers of hotels and 35 marketing managers of travel agencies located in Sharm El Sheikh, Hurghada and Cairo cities, as vital areas where the big presence of four and five star hotels and travel agencies class A. Validity and reliability were tested, then the questionnaires were modified according to respondents' comments. Data collected from a pilot study have been tabulated and analyzed using SPSS 21 statistical package as follow:

Table (1) Analyzing of pilot study for hotel marketing managers' data

\begin{tabular}{|l|l|l|l|}
\hline$\sigma^{2}$ & $\nearrow$ & $\bullet$ & Levene's Sig. \\
\hline 0.088 & 1.96 & 0.05 & 0.097 \\
\hline
\end{tabular}

Table (1) show that Levene's coefficient is not significant Sig=0.097, Levene's test is used to assess the homogeneity of a variable calculated for research samples. If the resulting p-value of Levene's test is more than some significance level (the researchers used 0.05 significance level) the obtained equal variances in samples are likely to have occurred based on random sampling from a population with equal variances (Nodstokke and Zumbo, 2010). The researchers used Cochran's formula of the sample size to calculate the research sample size as follow (Shkeeb, p, 2014):

$n=\frac{z^{2} \sigma^{2}}{e^{2}}$

\section{Where:}

$\sigma^{2}$ : variance of community:

standard degree: $\quad e$ maximum allowed error From the previous formula and table (1) the researchers calculated a convenient sample size for this research, where the maximum allowed error ( $\mathcal{C}$ ) was 0.05 , this value is suitable for discrete data (Shkeeb, p, 2014), standard degree ( $乙$ ) was 0.05 and the variance of the sample $\left(\sigma^{2}\right)$ was 0.088 . 
Applying these values to the Cochran's formula reveals that the appropriate sample size for marketing managers of hotels is 135 participants. Moreover, the appropriate sample size for marketing managers of travel agencies sample was calculated as follow:

Table (2) Analyzing of pilot study for travel agencies marketing managers data

\begin{tabular}{|l|l|l|l|}
\hline$\sigma^{2}$ & $\nearrow$ & $\bigodot$ & $\begin{array}{l}\text { Levene's } \\
\text { Sig. }\end{array}$ \\
\hline 0.078 & 1.96 & 0.05 & 0.097 \\
\hline
\end{tabular}

Applying the previous values to the Cochran's formula reveals that the appropriate sample size for marketing managers of hotels is 120 participants. Both online and offline questionnaires were employed in this study to reach out the target sample during the period from July to October 2017. A total of 121 questionnaires were collected from travel agencies, and about 138 questionnaires were collected from hotels. In total, this sample group consisted of a total of 259 respondents: $46.7 \%$ travel agencies and 53.3\% hotels. Table (1) showed the distribution of the sample.

Table (3) Profile of Sampled respondents

\begin{tabular}{|c|c|c|}
\hline & $\mathrm{F}$ & $\%$ \\
\hline Travel agencies & 121 & 46.7 \\
\hline hotels & 138 & 53.3 \\
\hline Total & 259 & 100.0 \\
\hline
\end{tabular}

\subsection{Survey Instrument}

Based on literature review, the survey tool is designed to cover six main study dimensions including: The awareness of digital content marketing, Benefits (objectives) of digital content marketing, Challenges of digital content marketing, the common tools of digital content marketing, the most measurement criteria for digital content marketing Success and the overall assessment of using digital content marketing. This study questionnaire consisted of 32 statements that measure the six main dimensions of this study. The five-point Likert scale was used to measure the sample opinions for each statement.

\subsection{Primary Data Analysis}

The collected data were analyzed using the Statistical Package for Social Science (SPSS version 21). Descriptive as well as inferential statistical methods were used. A detailed description of the study sample and scale reliability and validity testing were given. Also, the correlations test was used to examine the relationship between this study's dimensions. Moreover, T-test was used to compare the responses of the two target samples of this current study.

\section{Results}

As a preliminary step, it is important to examine the reliability of the study survey as well as to test the correlation between the study dimensions. The Cronbach alpha was calculated to examine the internal consistency reliability of the scale developed for this current study. In general, a scale's dimensions are to be reliable when it achieves value $(\alpha)$ over 0.7 (Bozorgy, 2007). Accordingly, it is clear that the proposed scale was reliable and valid for this study's purpose since the overall $\alpha$ was 0.918 (Table 2). The coefficients of Cronbach's Alpha for all scale's dimensions ranging from 0.735 to 0.913 indicated good internal consistency meaning that the associations among the study variables were reliable for further analysis. Details for all dimensions' values of Cronbach's alpha are provided in the table (2). 


\begin{tabular}{lll}
\hline \multicolumn{1}{c}{ Dimension } & No. of Items & $\begin{array}{c}\text { Cronbach's } \\
\text { alpha }\end{array}$ \\
\hline The awareness of digital content marketing & 2 & .735 \\
Benefits (objectives) of digital content marketing & 7 & .764 \\
Challenges of digital content marketing & 5 & .837 \\
the tools of digital content marketing & 9 & .913 \\
the most measurement criteria for digital content marketing & 6 & .900 \\
Success & & .719 \\
the overall assessment of using content marketing & 2 & .918 \\
Overall Scale & 32 &.. \\
\hline
\end{tabular}

In assessing the strength of the relationship between pairs of digital content marketing variables as reported by the sampled travel agencies and hotels, the Pearson Correlation was used. The correlation coefficients showed that there is a statistically significant weak to the strong positive relationship between each pair of the study dimensions. The only exception is the variable named challenges for digital content marketing which demonstrated no significant relationship to other content marketing's variables.

Table (5) Correlations between digital content marketing's variables

\begin{tabular}{|c|c|c|c|c|c|c|}
\hline \multicolumn{2}{|l|}{ Variables } & Awareness & Benefits & Challenges & $\begin{array}{l}\text { Common } \\
\text { Tools } \\
\end{array}$ & $\begin{array}{l}\text { Success } \\
\text { Criteria }\end{array}$ \\
\hline \multirow{3}{*}{ Benefits } & $r$ & $0.399 * *$ & & & & \\
\hline & $\begin{array}{l}\text { Sig } \\
\text { tailed })\end{array}$ & 0.000 & & & & \\
\hline & $\mathrm{N}$ & 259 & & & & \\
\hline \multirow{3}{*}{ Challenges } & $r$ & $0.001-$ & 0.106 & & & \\
\hline & $\begin{array}{l}\text { Sig } \\
\text { tailed })\end{array}$ & 0.984 & 0.090 & & & \\
\hline & $\mathrm{N}$ & 259 & 259 & & & \\
\hline \multirow{3}{*}{ Common Tools } & $\bar{r}$ & $0.226^{* * *}$ & $0.753^{* * *}$ & 0.041 & & \\
\hline & $\begin{array}{l}\text { Sig } \\
\text { tailed })\end{array}$ & 0.000 & 0.000 & 0.510 & & \\
\hline & $\mathrm{N}$ & 259 & 259 & 259 & & \\
\hline \multirow{3}{*}{ Success Criteria } & $\boldsymbol{r}$ & $0.405^{* * *}$ & $0.895^{\text {*** }}$ & 0.081 & $0.820^{3 * 6}$ & \\
\hline & $\begin{array}{l}\text { Sig } \\
\text { tailed })\end{array}$ & 0.000 & 0.000 & 0.192 & 0.000 & \\
\hline & $\mathrm{N}$ & 259 & 259 & 259 & 259 & \\
\hline \multirow{3}{*}{$\begin{array}{l}\text { Overall } \\
\text { Assessment }\end{array}$} & $r$ & $0.238^{* *}$ & $\underline{0.585}^{* *}$ & $0.051-$ & $0.699^{* * *}$ & $0.639^{* * *}$ \\
\hline & $\begin{array}{l}\text { Sig } \\
\text { tailed })\end{array}$ & 0.000 & 0.000 & 0.409 & 0.000 & 0.000 \\
\hline & $\mathrm{N}$ & 259 & 259 & 259 & 259 & 259 \\
\hline
\end{tabular}

Table (5) revealed the following positive relationship between each pair of variables:
- High correlation (marked relationship):

- The "Benefits of digital content marketing" and "Success criteria for 
digital content marketing" variables ( $r=$ $0.895, p=0.000$ );

- The "Common Tools of digital content marketing" and "Success criteria for digital content marketing" variables ( $r=$ $0.820, p=0.000)$;

- The "Benefits of digital content marketing" and "Common Tools of digital content marketing" variables $(r=0.753$, $p=0.000)$;

- The "Common Tools of digital content marketing" and "Overall assessment of using digital content marketing" variables $(r=0.699, p=0.000)$;

- The "Success criteria for digital content marketing" and "Overall assessment of using digital content marketing" variables $(r=0.639, p=0.000)$;

- Moderate correlation (substantial relationship):

- The "Benefits of digital content marketing" and "Overall assessment of using digital content marketing" variables $(r=0.585, p=0.000)$;

- The "Awareness of digital content marketing" and "Success criteria for digital content marketing" variables ( $r=$ $0.405, p=0.000)$;

- The "Awareness of digital content marketing" and "Benefits of digital content marketing" variables $(r=0.399$, $p=0.000)$;

- Low correlation (definite but small relationship:

- The "Awareness of digital content marketing" and "Overall assessment of using digital content marketing" variables $(r=0.238$, $p=0.000)$;

- The "Awareness of digital content marketing" and "Common Tools of digital content marketing" variables $(r=0.226, p=$ $0.000)$;
The above-mentioned findings ascertained that the studied variables of a digital content marketing move in the same direction meaning that the level of increase in one variable was correlated with increase another. Consequentially, understating these digital content marketing's variables is of importance in order to maximize the use efficiency and gains in the businesses environment of travel agencies and hotels in Egypt.

\subsection{Travel Agencies' Opinions Results}

The mean rank of all statements that measure travel agencies' awareness of content marketing was 4.45 (Table 4). This referred that travel agencies have a high degree of the awareness of content marketing.

Table (6) Travel Agencies' awareness of digital content marketing

\begin{tabular}{llll}
\hline Statements & & Mean & SD \\
\hline $\begin{array}{l}\text { I have awareness of content } \\
\text { marketing as a new }\end{array}$ & 4.45 & .658 \\
$\begin{array}{l}\text { marketing strategy. } \\
\text { Content marketing is an }\end{array}$ & & \\
$\begin{array}{l}\text { important component of my } \\
\text { company's } \\
\text { strategy. }\end{array}$ & & \\
Total & & & \\
\hline
\end{tabular}

As for the benefits of digital content marketing according to travel agencies opinion, the results showed that the highest mean score of these benefits was increasing sales rate at 5.00, followed by increasing customer engagement at 4.73, Increasing brand awareness at 4.64, Improving search engine rankings at 4.55 .

Table (7) Benefits of digital content marketing for travel agencies

\begin{tabular}{lcccc}
\hline Statements & & Mean & SD & Rank \\
\hline $\begin{array}{l}\text { Increasing } \\
\text { rate }\end{array}$ & sales & 5.00 & .000 & 1 \\
Increasing & & 4.73 & .447 & 2 \\
\hline
\end{tabular}




\begin{tabular}{lllll}
\hline $\begin{array}{l}\text { customer } \\
\text { engagement }\end{array}$ & & & \\
$\begin{array}{l}\text { Increasing brand } \\
\text { awareness }\end{array}$ & 4.64 & .645 & 3 \\
$\begin{array}{l}\text { Improving search } \\
\text { engine rankings }\end{array}$ & 4.55 & .658 & 4 \\
$\begin{array}{l}\text { Increasing website } \\
\text { traffic }\end{array}$ & 4.45 & .785 & 5 \\
$\begin{array}{l}\text { Increasing } \\
\text { customer loyalty }\end{array}$ & 4.36 & .775 & 6 \\
$\begin{array}{l}\text { Building the image } \\
\text { as the industry }\end{array}$ & 4.27 & .753 & 7 \\
leader & 4.49 & .384 & \\
\begin{tabular}{l} 
Total \\
\hline
\end{tabular} & & & \\
\hline
\end{tabular}

Concerning challenges of digital content marketing according to travel agencies sample opinion, the results indicated that the highest mean score of these challenges was creating a sufficient quality of content at 3.73, finding trained digital content marketing professionals at 3.73 , and inability to measure digital content effectiveness at 3.36

Table (8) Challenges of digital content marketing according to travel agencies opinions

\begin{tabular}{|c|c|c|c|}
\hline Statements & Mean & SD & Rank \\
\hline $\begin{array}{lr}\text { Creating } & \text { a } \\
\text { sufficient quality } \\
\text { of content }\end{array}$ & 3.73 & 1.218 & 1 \\
\hline $\begin{array}{l}\text { Finding trained } \\
\text { digital content } \\
\text { marketing } \\
\text { professionals }\end{array}$ & 3.73 & 1.218 & 2 \\
\hline $\begin{array}{l}\text { Inability to } \\
\text { measure digital } \\
\text { content } \\
\text { effectiveness }\end{array}$ & 3.36 & 1.372 & 2 \\
\hline $\begin{array}{l}\text { Creating a } \\
\text { sufficient quantity } \\
\text { (variety) of content }\end{array}$ & 3.00 & 1.211 & 4 \\
\hline Lack of Budget & 3.00 & 1.133 & 5 \\
\hline Total & 3.36 & .789 & \\
\hline
\end{tabular}

Table 9: showed the tools of digital content marketing that were used by the travel agencies' sample. The results revealed that the most practised tools were: Social Media platforms $(\mathrm{M}=4.55)$, followed by articles on travel agencies' websites $(M=4.50)$, and articles on other websites $(M=4.45)$. The lowest mean score of practised tools of content marketing was Mobile Apps ( $\mathrm{M}=3.64)$, followed by Digital Magazines $(M=3.82)$, and Blogs $(\mathrm{M}=4.00)$.

Table (9) The tools of digital content marketing being used by travel agencies

\begin{tabular}{lcccc}
\hline Statements & & Mean & SD & Rank \\
\hline $\begin{array}{l}\text { Social } \\
\text { platforms }\end{array}$ & Media & 4.55 & .894 & 1 \\
$\begin{array}{l}\text { articles on your } \\
\text { websites }\end{array}$ & 4.50 & .674 & 2 \\
$\begin{array}{l}\text { articles on other } \\
\text { websites }\end{array}$ & 4.45 & .785 & 2 \\
Videos & 4.27 & .866 & 4 \\
$\begin{array}{l}\text { E-mail } \\
\text { Newsletters }\end{array}$ & 4.00 & .742 & 5 \\
$\begin{array}{l}\text { Case Studies } \\
\text { Blogs }\end{array}$ & 4.00 & .957 & 6 \\
$\begin{array}{l}\text { Digital Magazines } \\
\text { Mobile Apps }\end{array}$ & 3.82 & 1.033 & 8 \\
total & 3.64 & 1.155 & 9 \\
\hline
\end{tabular}

Table 10: showed the most Success criteria for digital content marketing of travel agencies' sample. The results showed that the most practiced criteria were arranged as increasing Sales $(M=4.55)$, followed by website traffic $(\mathrm{M}=4.45)$, and increased customer engagement $(\mathrm{M}=4.36)$.

Table (10) Success criteria for digital content marketing of travel agencies

\begin{tabular}{lccl}
\hline Statements & Mean & SD & Rank \\
\hline Increasing Sales & 4.55 & .658 & 1 \\
Website Traffic & 4.45 & .894 & 2 \\
\hline
\end{tabular}




\begin{tabular}{|c|c|c|c|}
\hline $\begin{array}{l}\text { Increased customer } \\
\text { Engagement }\end{array}$ & 4.36 & .775 & 3 \\
\hline SEO Ranking & 4.27 & 966 & 4 \\
\hline $\begin{array}{ll}\text { Social } & \text { Media } \\
\text { Sharing } & \end{array}$ & 4.00 & 1.049 & 5 \\
\hline $\begin{array}{l}\text { Time Spent on } \\
\text { Website }\end{array}$ & 3.91 & .796 & 6 \\
\hline total & 4.26 & .708 & \\
\hline
\end{tabular}

As an overall assessment of using content marketing in travel agencies in Egypt, it can be stated that the sample of travel agencies was assessed CM as a success and more effective strategy (table 11).

Table (11) The overall assessment of using digital content marketing for travel agencies

\begin{tabular}{|l|c|l|}
\hline Statements & Mean & SD \\
\hline $\begin{array}{l}\text { Digital content marketing strategy is } \\
\text { success }\end{array}$ & 4.64 & .483 \\
\hline $\begin{array}{l}\text { Digital content marketing is more } \\
\text { effective }\end{array}$ & 4.73 & .447 \\
\hline Total & 4.68 & .387 \\
\hline
\end{tabular}

\subsection{Hotel's Opinions Results}

It can be seen from Table 10 that the mean rank of the statements that evaluate hotels' awareness of digital content marketing ranged from 3.91 to 4.46. This means that sampled staff members have a high level of awareness of content marketing.

Table (12) Hotels' awareness of digital content marketing

\begin{tabular}{llcl}
\hline Statements & Mean & SD \\
\hline $\begin{array}{l}\text { I have awareness of digital content } \\
\text { marketing as a new marketing }\end{array}$ & & \\
$\begin{array}{l}\text { strategy. } \\
\text { Digital content marketing is an }\end{array}$ & 4.46 & .716 \\
$\begin{array}{l}\text { important component of my hotel's } \\
\text { marketing strategy. }\end{array}$ & & \\
Total & 4.18 & .689 \\
\hline
\end{tabular}

With respect to the objectives of digital content marketing according to hotels' views, the results in table 11 revealed that the highest mean score of those objectives were "Increasing sales rate" at 4.87, "Increasing brand awareness" at 4.87, "Increasing customer engagement" at 4.74, and "Improving search engine rankings" and "Increasing website traffic" at 4.46

Table (13) Benefits of digital content marketing for hotels

\begin{tabular}{|c|c|c|c|}
\hline Statements & Mean & SD & Rank \\
\hline Increasing sales rate & 4.87 & .338 & 1 \\
\hline $\begin{array}{l}\text { Increasing } \quad \text { brand } \\
\text { awareness }\end{array}$ & 4.87 & .338 & 2 \\
\hline $\begin{array}{l}\text { Increasing customer } \\
\text { engagement }\end{array}$ & 4.74 & .441 & 3 \\
\hline $\begin{array}{l}\text { Improving search engine } \\
\text { rankings }\end{array}$ & 4.46 & .716 & 4 \\
\hline $\begin{array}{l}\text { Increasing } \quad \text { website } \\
\text { traffic }\end{array}$ & 4.46 & .716 & 5 \\
\hline $\begin{array}{l}\text { Increasing customer } \\
\text { loyalty }\end{array}$ & 4.74 & .441 & 6 \\
\hline $\begin{array}{l}\text { Building the image as } \\
\text { the industry leader }\end{array}$ & 4.87 & .338 & 7 \\
\hline Total & 4.66 & .367 & \\
\hline
\end{tabular}

The challenges that faced hotels in using digital content marketing were arranged as: "creating a sufficient quality of content" $(\mathrm{M}=4.02)$, "finding trained digital content marketing professionals" $(\mathrm{M}=3.87)$, and "lack of budget" (M=3.79) (table 14)

Table (14) Challenges of digital content marketing according to hotels opinions

\begin{tabular}{|c|c|c|c|}
\hline Statements & Mean & SD & Rank \\
\hline $\begin{array}{l}\text { Creating a sufficient } \\
\text { quality of content }\end{array}$ & 4.02 & 1.097 & 1 \\
\hline $\begin{array}{l}\text { Finding Trained digital } \\
\text { content } \\
\text { professionals }\end{array}$ & 3.87 & .995 & 2 \\
\hline Lack of Budget & 3.79 & 1.027 & 3 \\
\hline $\begin{array}{l}\text { Inability to } \begin{array}{r}\text { Measure } \\
\text { digital }\end{array} \\
\text { effectiveness }\end{array}$ & 3.59 & 1.333 & 4 \\
\hline $\begin{array}{ll}\text { Creating a sufficient } \\
\text { quantity } \\
\text { content }\end{array}$ & 3.46 & 1.430 & 5 \\
\hline
\end{tabular}

Table 15 illustrated that the most tools of digital content marketing that are used by the 
hotels were; Videos and Mobile Apps ( $\mathrm{M}=$ 4.74), followed by articles on hotels' websites $(\mathrm{M}=4.59)$, and Social Media platforms $(\mathrm{M}=$ 4.57). The lowest mean score of tools were Blogs at 4.04 , followed by case studies at 4.22 , and articles on other websites at 4.33.

Table (15) The tools of digital content marketing being used by hotels

\begin{tabular}{lccl}
\hline Statements & Mean & SD & Rank \\
\hline Videos & 4.74 & .441 & 1 \\
Mobile Apps & 4.74 & .441 & 2 \\
$\begin{array}{l}\text { articles on your } \\
\text { websites }\end{array}$ & 4.59 & .494 & 3 \\
Social Media platforms & 4.57 & .744 & 4 \\
E-mail Newsletters & 4.46 & .716 & 5 \\
Digital Magazines & 4.46 & .716 & 6 \\
articles on other & 4.33 & .864 & 7 \\
websites & & & \\
Case Studies & 4.22 & 1.418 & 8 \\
Blogs & 4.04 & 1.183 & 9 \\
total & 4.46 & .689 & \\
\hline
\end{tabular}

The most measurement criteria that are used by hotels to assess the digital content marketing success were arranged as: "Increasing Sales" and "Increased customer Engagement" at 4.59, followed by "Social Media Sharing" at 4.46 (table 16).

Table (16) The Success criteria for digital content marketing of hotels

\begin{tabular}{lccl}
\hline Statements & Mean & SD & Rank \\
\hline Increasing Sales & 4.59 & .494 & 1 \\
Increased customer Engagement & 4.59 & .494 & 2 \\
Social Media Sharing & 4.46 & .500 & 3 \\
SEO Ranking & 4.20 & 1.100 & 4 \\
Time Spent on Website & 4.20 & 1.100 & 5 \\
Website Traffic & 4.07 & 1.055 & 6 \\
total & 4.35 & .704 & \\
\hline
\end{tabular}

As an overall assessment of using digital content marketing in hotels, it can be stated that the sample of hotels was assessed DCM as a success and more effective strategy (Table 17).
Table (17) The overall assessment of using digital content marketing for hotels

\begin{tabular}{lcc}
\hline Statements & Mean & SD \\
\hline $\begin{array}{l}\text { Digital content marketing } \\
\text { strategy is success }\end{array}$ & 4.59 & .712 \\
$\begin{array}{l}\text { Digital content marketing } \\
\text { is more effective }\end{array}$ & 4.59 & .494 \\
Total & 4.59 & .557 \\
\hline
\end{tabular}

\subsection{Differences between the views of travel agencies and hotels on the study variables}

An independent-samples t-test was conducted to compare opinions of travel agencies against hotels towards digital content marketing variables. These t-test results are given in the following tables and figures. It is evident from a table (18) that the mean of "awareness of digital content marketing" score of travel agencies is 4.45 with standard deviation 0.692 and the mean score of hotels is 4.18 with standard deviation 0.689 . The calculated $t$ value is 2.953 , which exceeds table value at .05 level. So, it can result that there a significant difference in "awareness of digital content marketing" between travel agencies and hotels. It is also obvious that the mean "awareness of digital content marketing" score of travel agencies is higher than that of hotels, revealing that travel agencies are better in the awareness of content marketing than the hotels.

Table (18) Summary of N, Mean, SD, df and t-value for "awareness of digital content marketing" of travel agencies and hotels

\begin{tabular}{|l|l|l|l|l|l|}
\hline Group & $\mathrm{N}$ & Mean & $\mathrm{SD}$ & $\mathrm{df}$ & $\mathrm{T}$-value \\
\hline $\begin{array}{l}\text { Travel } \\
\text { Agencies }\end{array}$ & 121 & 4.49 & 0.384 & 257 & $3.465^{*}$ \\
\cline { 1 - 4 } Hotels & 138 & 4.66 & 0.367 & & \\
\hline
\end{tabular}

* Significant at .05 level

Table (19) illustrated t-test results for "benefits of digital content marketing", the mean score of travel agencies is 4.49 with standard 
deviation 0.384 and mean score of hotels is 4.66 with standard deviation 0.367. The calculated t-value is 3.465 , which is greater than table value at 0.05 level, which means that there are significant differences in the "benefits of digital content marketing" value between travel agencies and hotels. It is also apparent that the score of the mean of "benefits of digital content marketing" of hotels is higher than the Mean score of travel agencies referring that hotels are better in benefits of content marketing value than the travel agencies."

Table (19) Summary of N, Mean, SD, df and t-value for "benefits of digital content marketing" of travel agencies and hotels

\begin{tabular}{|l|l|l|l|l|l|}
\hline Group & N & Mean & SD & df & $\begin{array}{l}\text { T- } \\
\text { value }\end{array}$ \\
\cline { 1 - 4 } $\begin{array}{l}\text { Travel } \\
\text { Agencies }\end{array}$ & 121 & 4.45 & 0.692 & 257 & $2.953^{*}$ \\
\cline { 1 - 4 } Hotels & 138 & 4.18 & 0.689 & & \\
\hline
\end{tabular}

Significant at .05 level

As for the "challenges for digital content marketing", table (20) showed that the mean score value of travel agencies is 3.36 with standard deviation 0.789 and for hotels, it is 3.79 with standard deviation 1.027. The calculated t-value comes out to be 3.719 , which is greater than that of table value at 0.05 level. So, there is exists a significant difference in the "challenges for digital content marketing" of travel agencies and hotels. It is also understandable that the mean of "challenges for digital content marketing" score of hotels is higher than that score of travel agencies. It means that hotels are facing more challenges than travel agencies with respect to the adopting of content marketing.
Table (20) Summary of N, Mean, SD, df and t-value for "challenges for digital content marketing" of travel agencies and hotels

\begin{tabular}{|l|l|l|l|l|l|}
\hline Group & $\mathrm{N}$ & Mean & $\mathrm{SD}$ & $\mathrm{df}$ & $\mathrm{T}$-value \\
\hline $\begin{array}{l}\text { Travel } \\
\text { Agencies }\end{array}$ & 121 & 3.36 & 0.789 & 257 & $3.719 *$ \\
\cline { 1 - 5 } Hotels & 138 & 3.79 & 1.027 & & \\
\hline
\end{tabular}

* Significant at 0.05 level

In examining the difference in the views of sampled travel agencies and hotels with respect to the "common tools of digital content marketing", it is observed that the mean score of travel agencies is 4.13 with standard deviation 0.609 and the mean score of hotels is 4.46 with standard deviation 0.689. The calculated ' $t$ ' value shown in the table (21) is 4.060 , which is greater than table value at 0.05 level. So, it is indicated that there is exists a significant difference in the "common tools of digital content marketing" used by travel agencies and hotels. It is also clear that the mean of "common tools of digital content marketing" score of hotels is higher than the score of travel agencies. It means that hotels are using more tools for content marketing than travel agencies.

Table (21) Summary of N, Mean, SD, df and t-value for "common tools of digital content marketing" of travel agencies and hotels

\begin{tabular}{|l|l|l|l|l|l|}
\hline Group & $\mathrm{N}$ & Mean & $\mathrm{SD}$ & $\mathrm{df}$ & $\mathrm{T}$-value \\
\hline $\begin{array}{l}\text { Travel } \\
\text { Agencies }\end{array}$ & 121 & 4.13 & 0.609 & 257 & $4.060^{*}$ \\
\cline { 1 - 4 } Hotels & 138 & 4.46 & 0.689 & & \\
\hline
\end{tabular}

* Significant at 0.05 level

As for, the other two study's variables, "success criteria for digital content marketing" and "overall assessment of using digital content marketing", the significant levels were 0.305 and 0.118 respectively (Table 22). Since these values are greater than 0.05 , hence there 
was no significant difference between the views of travel agencies and hotels regarding these two variables.

Table (22) t-test results of "success criteria for digital content marketing" and "overall assessment of using digital content marketing" scores

\begin{tabular}{|c|c|c|c|c|c|c|c|c|c|c|}
\hline & \multicolumn{2}{|c|}{$\begin{array}{|lr|}\text { Levene's } & \text { Test } \\
\text { Equality } & \text { of } \\
\text { Variances } & \\
\end{array}$} & \multicolumn{7}{|c|}{ t-test for Equality of Means } \\
\hline & & \multirow[t]{2}{*}{$F$} & \multirow[t]{2}{*}{ Sig. } & \multirow[t]{2}{*}{$\mathrm{t}$} & \multirow[t]{2}{*}{ Df } & \multirow{2}{*}{$\begin{array}{l}\text { Sig (2- } \\
\text { tailed) }\end{array}$} & \multirow{2}{*}{$\begin{array}{l}\text { Mean } \\
\text { Diff. }\end{array}$} & \multirow{2}{*}{$\begin{array}{l}\text { Std. } \\
\text { Error } \\
\text { Diff. }\end{array}$} & \multicolumn{2}{|c|}{$\begin{array}{l}95 \% \text { Confidence } \\
\text { Interval of the Diff. }\end{array}$} \\
\hline & & & & & & & & & Lower & Upper \\
\hline \multirow{2}{*}{$\begin{array}{l}\text { Success } \\
\text { Criteria } \\
\text { DCM }\end{array}$} & $\begin{array}{l}\text { Equal variances } \\
\text { assumed }\end{array}$ & .798 & .373 & $-1.027-$ & 257 & .305 & $-.090-$ & .088 & $-.263-$ & .083 \\
\hline & $\begin{array}{l}\text { Equal variances } \\
\text { not assumed }\end{array}$ & & & $-1.027-$ & 252.191 & .306 & $-.090-$ & .088 & $-.263-$ & .083 \\
\hline \multirow{2}{*}{$\begin{array}{l}\text { Overall } \\
\text { Assessment of } \\
\text { using DCM }\end{array}$} & $\begin{array}{l}\text { Equal variances } \\
\text { assumed }\end{array}$ & 23.411 & .070 & 1.570 & 257 & .118 & .095 & .060 & $-.024-$ & .214 \\
\hline & $\begin{array}{l}\text { Equal variances } \\
\text { not assumed }\end{array}$ & 2.342 & .127 & 1.607 & 244.827 & 109 & .095 & .059 & $-.021-$ & .211 \\
\hline
\end{tabular}

\section{Discussions and conclusion}

In the digital marketing of hospitality, content marketing means taking a holistic view of all of the establishment's digital content and aiming to have this content answer its customers' needs as opposed to present them with just facts. Such content (in whatever form e.g. text, imagery, video, virtual tour etc.) is then distributed through establishment's digital marketing channels such as on hotel website, in email marketing campaigns and in social media updates (Andreopoulou, 2014). This study was designed to explore the usage of digital content marketing in both travel agencies and hotels in Egypt. To achieve the purpose and objectives of this research, the study targeted the population of hotels and travel agencies in Egypt. The validity and reliability of the study tools were practically measured by presenting them to a group of industry experts and statistical experts, as well as they statistically measured by using Cronbach's Alpha coefficient, the Cochran's formula was used to determine the optimal sample size based on the pilot study results. The gathered primary data were analyzed using different descriptive as well as inferential statistical methods.

The results indicated that both travel agencies and hotels in Egypt have a high degree of the awareness of digital content marketing. The overall assessment of using DCM in travel agencies and hotels was a successful and very effective marketing strategy. The findings showed that there was found a statistically significant correlation between each pair of the study dimensions. The only exception is the variable named "challenges for digital content marketing" which demonstrated no significant relationship to other content marketing's variables. The high relationships (Strong relationship) were between the dimensions of "Benefits of digital content marketing" and "Success criteria for digital content marketing"; "Common Tools of digital content marketing" and "Success criteria for digital 
content marketing"; "Benefits of digital content marketing" and "Common Tools of digital content marketing"; "Common Tools of content marketing" and "Overall assessment of using content marketing"; "Success criteria for digital content marketing" and "Overall assessment of using digital content marketing". Moreover, there were significant differences in "awareness of digital content marketing" between travel agencies and hotels, these differences were favor travel agencies and reveal the travel agencies are better in the awareness of digital content marketing than the hotels. Hence, there were significant differences in the "benefits of digital content marketing" value between travel agencies and hotels, these differences were favor hotels and refer that hotels are better in benefits of content marketing value than the travel agencies. There were significant differences in the "challenges for content marketing" between travel agencies and hotels, these differences were favour hotels and means that hotels are facing more challenges than travel agencies with respect to the adopting of content marketing. There were significant differences in the "common tools of digital content marketing" used by travel agencies and hotels, these differences were favour hotels and means that hotels are using more tools for content marketing than travel agencies. On the other hand, there were no significant differences between the views of travel agencies and hotels regarding the dimensions of "success for digital content marketing" and "overall assessment of using digital content marketing". The most benefits of digital content marketing for both travel agencies and hotels were "increasing sales rate", "increasing customer engagement" and "Increasing brand awareness." These results were consistent with the results of some previous studies (Elisa and Gordini, 2014, CMI, 2015, CMI,2016 b, CMI, 2017 a, Gerard,
2014, Holliman and Rowley, 2014. and Gerard, 2015). The most challenges of digital content marketing that faced travel agencies and hotels were "Creating a sufficient quality of most digital content marketing", "Finding trained most digital content marketing professionals", "Inability to measure content effectiveness" and "Lack of budget". This was agreed with the results of the studies conducted by CMI $(2015,2016$ b).

The most common tools of digital content marketing being used by travel agencies were "Social media platforms", Followed by "Articles on travel agencies' websites" and "Articles on other websites". But the most common tools of DCM being used by hotels were "Videos", "Mobile apps", "Articles on hotels' websites" and "Social media platforms". This was agreed with the results of the studies (Elisa and Gordini, 2014, CMI, 2015, CMI,2016 b, CMI, 2017 a). Both travel agencies and hotels used increasing sales, website traffic, increased customer engagement and social media sharing as success criteria for digital content marketing. This was consistent with the results of some previous studies (Gerard, 2014, Gerard, 2015, CMI, 20105, CMI, 2016 b).

\section{Recommendation}

This study presented few recommendations that are useful for the travel agencies and hotels including:

- Using digital content marketing DCM as the main strategy and developing plans for travel agencies and hotels in order to increase performance, efficiency and create value.

- Creating a sufficient quality and quantity of contents, and increasing and diversification of DCM tools being used by travel agencies and hotels such 
as videos, blogs social media enewsletter....etc.

- Increasing training programs of human resources generally in e-marketing specifically in DCM.

\section{References}

1. Ahmad, NS; Musa, R; Harris, M, and Harun, M (2016). "The Impact of Social Media Content Marketing (SMCM) towards Brand Health", ScienceDirect, Procedia Economics and Finance, Vol. 37, pp.331 - 336.

2. Andreopoulou, Z, Tsekouropoulos, G, Koliouska, C, and Koutroumanidis, T (2014). "Internet Marketing for Sustainable Development and Rural Tourism", International Journal of Business Information Systems, vol. 16, pp. 446-461.

3. Augustini, M (2014). "Social Media and Content Marketing as a part of an effective Online Marketing strategy", Diploma thesis, Faculty of informatics, Masaryk University, Brno.

4. Chasser, A, and Wolfe, J (2010). "Brand Rewired: Connecting Branding, Creativity, and Intellectual Property Strategy Hardcover". San Francisco: Willey.

5. CMI, Content Marketing Institute (2013 a), "B2B Content Marketing: 2013 Benchmarks, Budgets, and Trends", Report for North American marketers.

6. CMI, Content Marketing Institute, $(2013$ b). What is Content Marketing? [Online] Available at: http://contentmarketinginstitute.com/what-iscontent-marketing/ [Accessed 30 September 2013].

7. CMI, Content Marketing Institute (2014), "B2C Content Marketing 2014 Benchmarks, Budgets and Trends-North America", report.

8. CMI, Content Marketing Institute (2015), "B2C Content Marketing 2015 Benchmarks, Budgets and Trends-North America", report.

9. CMI, Content Marketing Institute (2016 a), "B2C Content Marketing 2016 Benchmarks, Budgets and Trends-North America", report.

10. CMI, Content Marketing Institute (2016 b), "Content Marketing in Australia 2016: Benchmarks, Budgets and Trends, Australia report.

11. CMI, Content Marketing Institute (2016 c). 2016 Content Marketing Playbook. http://contentmarketinginstitute.com/wpcontent/uploads/2016/04/content-marketingplaybook-2016.pdf $+\& \mathrm{~cd}=1 \& \mathrm{hl}=\operatorname{ar} \& \mathrm{ct}=\mathrm{clnk} \& \mathrm{gl}=\mathrm{eg}$
12. CMI, Content Marketing Institute (2017 a), "B2B Content Marketing 2017 Benchmarks, Budgets and Trends-North America", report.

13. CMI, Content Marketing Institute (2017 b), "B2B enterprise Content Marketing 2017 Benchmarks, Budgets and Trends-North America", report.

14. Constantinescu-Dobra A (2014). "Content Marketing on Dentist's Websites. An Empirical Comparative Study between Romania and the UK, International Conference on Advancements of Medicine and Health Care through Technology", IFMBE Proceedings, vol. 44, Springer International Publishing, pp. 107-112.

15. Content Marketing Expert Project, (2014). "Content Marketing Handbook, Simple Ways to Innovate Your Marketing Approach", European Commission, Lifelong Learning Program.

16. Duc Le M, (2013). Content Marketing, Bachelor's Thesis DP in International Business, Haaga-Helia University of Applied Sciences, Finland

17. Egypt hotel guide, 2016. Ministry of Tourism, Information Center.

18. Elisa, R and Gordini, N (2014). Content Marketing Metrics: "The Cortical Specters and Empirical Evidence", European Scientific Journal, vol.10, pp 92-104.

19. Gagnon, E (2014). "Goodbye, B2B Brand Marketing: Developing Content-Based Marketing Programs for the Post-Marketing Era". International Management Review, vol 10, pp. 68-71.

20. Gagnon, E (2014). Goodbye, B2B Brand Marketing: "Developing Content-Based Marketing Programs for the Post-Marketing Era. International Management Review", vol. 10. pp. 68-71.

21. Gererd, M (2014). "Content Marketing Tactics: Creation, Curation and Syndication". Curate. Available online: https://www.curata.com/files/webinar-contentmarketing-tactics-2014/slides.pdf

22. Gerard, M (2015). "Content Marketing Tactics \& Technology Planner Creation, Curation \& Analytics. Curate". Available online: https://www.curata.com/resources/ebooks/contentmarketing-tactics-technology-planner

23. Gutman, B, (2012). "5 Big Brands Confirm That Content Marketing Is The Key to Your Consumers". Retrieved on 10 August 2015 from.http://www.forbes.com/sites/marketshare/201 2/11/27/5-big-brands-confirm-that-contentmarketing-is-the-key-to-your-consumer/

24. Halvorson, K (2010). "Content strategy for the web". New Riders: Berkeley. 
25. Holliman, G, and Rowley, J (2014). "Business to business digital content marketing: marketers' perceptions of best practice". Journal of research in interactive marketing, vol. 8, pp. 269-293.

26. Jefferson, S. and Tanton, S (2013). "Valuable Content Marketing. How to make quality content the key to your business success". Kogan Page: London.

27. Lieb, R (2011)."Content Marketing: Think Like a Publisher. How to Use Content to Market Online and in Social Media". Que Publishing: Indianapolis.

28. Mackenzie, J (2016), "The Concierge Approach to Content Marketing, Hotel Marketing Strategies,

29. Marketing Intelligence Report (2015)."Content Marketing Tools: A Marketer's Guide", A Digital Marketing Depot Research Report.

30. Mathey, A (2015). "Content Marketing: Creative Content Marketing for Canadian Artist and Cultural Organizations. Culturedays.ca

31. Nodstokke, W.D, and Zumbo, D.B, (2010), "A New Nonparametric Levene test for Equal Variances, Psychologica Vol. 31, pp. 401-430.

32. PATA, 2016. "Storytelling and Content Marketing Strategies for the Travel Industry", Pacific Asia Travel Association, Visitor Economy Bulletin, Dec 2016.

33. Pažèraitè, A, and Repovienè, R (2016), "Content Marketing Decisions Application for Rural Tourism Development": Case Study of ' Illankos Sodyba' , Research for Rural Development, vol. 2, pp. 143 149.

34. Pulizzi, J (2012), "Six Useful Content Marketing Definitions", Chief Content Officer Review, June 6, 2012,

35. Rancati, E, and Gordini, N (2014). "Content marketing metrics: Theoretical aspects and empirical evidence. European Scientific Journal, ESJ, 10(34).

36. Rose, R. and Pulizzi, J (2011). "Managing Content Marketing". The real-world guide for creating passionate subscribers to your brands. CMI Books: Cleveland.

37. Rose, R, and Pulizzi, J (2011). "Managing Content Marketing: The Real-World Guide for Creating Passionate Subscribers to Your Brand. BookBaby".

38. Rowley, J (2008). "Understanding Digital Content Marketing". Journal of Marketing Management, vol.24, pp.517-540.

39. Schuinanii, J, Wangenheim, F, and Groene, N (2014). "Targeted Online Advertising: Using Reciprocity Appeals to Increase Acceptance Among Users of Free Web Services". Journal of Marketing, vol. 78, pp. 59-75.
40. Skift (2013). "Content Marketing Trends in the Travel Industry". https://research.skift.com/reports/contentmarketing-trends-in-the-travel-industry/ (10/3/2017)

41. Skift (2016). Winning Content Marketing Strategies for 2016", New Skift Trends Report. https://skift.com/2016/03/10/new-skift-trendsreport-winning-content-marketing-strategies-for2016/ (10/3/2017)

42. Swieczak W (2012). " Content Marketing as an Important Element of Marketing Strategy of Scientific Institutions", Marketing of scientific and research organization, vol.51, pp. 133- 150.

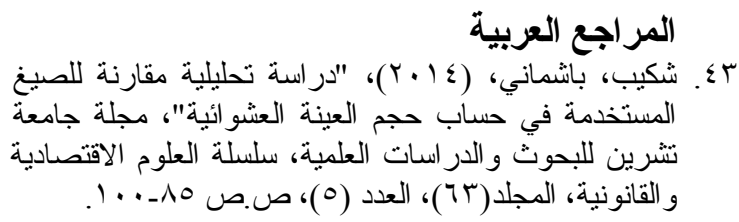

10. List of Abbreviations:

- DCM (digital content marketing)

- CMI (Content Marketing Institute)

- B2B (Business 2 Business)

- B2C (Business 2 Customer)

- SEO (search engine optimization) 